\title{
KONCEPT MATERIJALNOSTI SA STANOVIŠTA FINANSIJSKOG I NEFINANSIJSKOG IZVEŠTAVANJA
}

\author{
Jozefina Beke-Trivunac \\ ALFA BK Univerzitet, Palmira Toljatija 3, Novi Beograd, Srbija
}

\begin{abstract}
Apstrakt:
Materijalnost predstavlja prag značajnosti za odlučivanje o tome koja su to pitanja dovoljno važna da bi bila uključena u izveštaj. Prema Konceptualnom okviru za finansijsko izveštavanje "materijalnost je aspekt relevantnosti svojstven određenom entitetu koji je zasnovan na prirodi ili veličini, ili na obe stavke na koje se informacije odnose".

Finansijske informacije ne predstavjaju samo merodavne pojave, već moraju verodostojno da predstave i svrhu tih pojava. Sve veći značaj nefinansijskog izveštavanja nametnuo je vodećim kompanijama potrebu da samostalno pronalaze rešenja za određivanje onoga šta se smatra materijalno značajnom informacijom, uzimajući u obzir potrebe interesnih strana, ograničenja koja su nametnuta prirodnom sredinom i shodno svojim strateškim ciljevima.

Za potrebe interesnih strana, koncept materijalnosti neophodno je posmatrati kako sa stanovišta obuhvatnosti izveštavanja, tako i sa stanovišta obuhvatnosti uveravanja.
\end{abstract}

\section{UVOD}

Računovodstveni koncepti i principi su skup opšteprihvaćenih konvencija koje čine osnovu na kojoj se zasniva okvir finansijskog izveštavanja, na primer Konceptualni okvir za finansijsko izveštavanje koji je izdao Odbor za međunarodne računovodstvene standarde (IASB). U opšteprihvaćene principe računovodstvenog izveštavanja ubrajaju se merodavnost (relevantnost) i verodostojnost prikazivanja (potpunost i tačnost, bez grešaka, što ih čini pouzdanim), pre svega materijalno značajnih iznosa i informacija, a zatim njihova uporedivost sa podacima i informacijama iz drugih izveštaja, proverljivost tih podataka i informacija, kao i blagovremenost i razumljivost njihovog izveštavanja (Odbor za međunarodne računovodstvene standarde - IASB, Okvir 2010).

Koncept materijalnosti tesno je povezan sa nekoliko drugih računovodstvenih koncepata, pre svega sa konceptima „merodavnosti”, „pouzdanosti” i „potpunosti”. Informacija je merodavna, ako utiče na ekonomske odluke korisnika finansijskih izveštaja. Izostavljanje informacije umanjuje pouzdanost finansijskih izveštaja. Koncept potpunosti zahteva uključivanje svih materijalno značajnih pitanja u finansijske izveštaje. U tom smislu, informacije sadržane u finansijskim izveštajima moraju biti potpune po svim materijalno značajnim pitanjima, radi pružanja istinitog i poštenog pogleda na poslovanje entiteta.

Od navedenih koncepata u ovom radu izdvajamo koncept materijalnosti koji je bitan i za utvrđivanje korporativnih i društvenih pitanja i pitanja prirodnog okruženja koja imaju značajan učinak na poslovanje i interesne strane organizacije i sa njima povezane rizike. Sve veći broj okvira za nefinansijsko izveštavanje, kao što su smernice i računovodstveni standardi, od kojih su najpoznatiji: Globalna ini- cijativa za izveštavanje (Global Reporting Initiative's - GRI), Međunarodni okvir integrisanog izveštavanja (International Integrated Reporting Framework) i računovodstveni standardi održivosti (Sustainability Accounting Standards - SAS) u SAD iznova pokreću rasprave o načinu primene koncepta materijalnosti za ove potrebe. Zajednička odlika svih ovih okvira je da se pozivaju na koncept materijalnosti, ali nijedan od njih ne sadrži bliže odrednice tog koncepta, a pogotovo ne kvantifikaciju pojma materijalnosti. Čak i nova regulativa, kao što je Evropska direktiva o nefinansijskom izveštavanju (European Directive on non-financial reporting) ostavlja organizacijama da procene koje su to značajne nefinansijske informacije o kojima bi trebalo izveštavati. Istraživanja pokazuju da, izuzev u retkim slučajevima, kompanije prikazuju i obelodanjuju nematerijalne informacije najviše zbog izbegavanja komentara ili privlačenja pažnje regulatornih $\mathrm{i}$ nadzornih organa (CFA Institute, 2013, str. 21).

\section{KONCEPT MATERIJALNOSTI U FINANSIJSKOM IZVEŠTAVANJU}

U članku „Empirijsko istraživanje koncepta materijalnosti u računovodstvu", Frishkoff posmatra koncept materijalnosti kao jedan od kamena temeljca računovodstva, pri čemu polazi od pretpostavke „da je svaka stavka koja se razmatra, u nekom smislu materijalna" implicitno ugrađena u svaku odluku o iskazivanju datog događaja u računovodstvenim evidencijama, ili za potrebe klasifikacije transakcija, ili radi rasprave o nekom kontroverznom računovodstvenom pristupu. Definisanje materijalnosti sa računovodstvenog stanovišta mora da uzme u obzir relativan i kvantitativan značaj neke finansijske informacije u kontekstu odluka koje određeni korisnik donosi (Frishkoff, 1970). 
Okviri za finansijsko izveštavanje razmatraju koncept materijalnosti u kontekstu izrade i prikazivanja finansijskih izveštaja. Iako ovi okviri razmatraju koncept materijalnosti sa različitih stanovišta, svi imaju nekoliko zajedničkih osobina:

1) Pogrešno iskazani iznosi, uključujući i izostavljanje, smatraju se materijalnim ako, pojedinačno ili u zbiru, mogu da utiču na ekonomske odluke koje korisnik donosi na osnovu tih finansijskih izveštaja;

2) Prosuđivanje o materijalnosti vrši se u kontekstu datih okolnosti, i uzima u obzir veličinu i prirodu pogrešno iskazanih iznosa, ili njihovu kombinaciju; i

3) Prosuđivanja o činjenicama koje se smatraju materijalno značajnim sa stanovišta zajedničkih potreba korisnika finansijskih informacija kao grupe.

Mogući učinak pogrešnog iskazivanja sa stanovišta pojedinačnog korisnika, čije potrebe mogu da variraju u širokom rasponu, ne uzimaju se u obzir (International Auditing and Assurance Standards Board -IAASB, 2014).

Prema Konceptualnom okviru za finansijsko izveštavanje, „informacija je materijalno značajna ako njeno izostavljanje ili pogrešno prikazivanje može da utiče na odluke koje korisnici prave na osnovu finansijskih informacija o određenom izveštajnom entitetu" (Odbor za međunarodne računovodstvene standarde -IASB, Okvir 2010). Ova definicija materijalnosti povezana je sa odlukama koje donose korisnici finansijskih izveštaja opšte namene. Primarni korisnici finansijskih izveštaja navedeni su u Konceptualnom okviru finansijskog izveštavanja i obuhvataju postojeće i potencijalne investitore, zajmodavce i druge kreditore koji nisu u mogućnosti da zahtevaju od izveštajnih entiteta da svoje finansijske izveštaje dostavljaju direktno njima. U procesu pripreme finansijskih i drugih izveštaja, rukovodstvo entiteta treba da sagleda njihove karakteristike i vrste odluka koje ovi subjekti donose. Procenjena očekivanja ovih korisnika čine razumnu osnovu za izbor informacija koje mogu da utiču na njihove odluke. MRS 1 Prikazivanje računovodstvenih izveštaja, dopunjuje pojam materijalnosti tako što pored kvantitativnih zahteva (veličina) zahteva utvrđivanje kvalitativnih karakteristika (priroda) stavke koja se razmatra (Odbor za međunarodne računovodstvene standarde - IASB, IAS 1, stav 7).

Specifičnost pitanja materijalnosti ogleda se u pojavi grešaka u procesu priznavanja, odmeravanja, prikazivanja i obelodanjivanja podataka u finansijskim izveštajima. Da bi finansijski izveštaji bili u skladu sa Međunarodnim standardima finansijskog izveštavanja (IFRS) neophodno je da ne sadrže materijalno značajne greške, kao i namerno načinjene nematerijalne greške sa ciljem prikazivanja određene finansijske pozicije i/ili određenog rezultata poslovanja u finansijskim izveštajima (Odbor za međunarodne računovodstvene standarde - IASB, IAS 8, stav 41).

Procena da li izostavljanje ili pogrešno iskazivanje može uticati na ekonomske odluke korisnika, i zbog toga biti materijalno značajno, zahteva razmatranje karakteristika ovih korisnika. Okvir za sastavljanje i prezentaciju finansijskih izveštaja u paragrafu 25 navodi da „se pretpostavlja da korisnici poseduju razumno znanje o poslu, ekonomskoj aktivnosti i računovodstvu i da su voljni da informacije proučavaju sa dužnom pažnjom.” Zbog toga, procena treba da uzme u obzir koliko je opravdano očekivati da će korisnici sa takvim karakteristikama biti pod ovim uticajem prilikom donošenja svojih ekonomskih odluka (Odbor za međunarodne računovodstvene standarde - IASB, IAS 1).
Na Diskusionom forumu o obelodanjivanju u finansijskim izveštajima, koji je IASB održao u januaru 2013. godine razmatrane su poteškoće koje se javljaju pri primeni koncepta materijalnosti u praksi, tokom pripreme finansijskih izveštaja. Prepoznat je veliki broj činilaca zbog kojih se koncept materijalnosti ne primenjuje dobro u praksi. Jedan od ovih činioca je i ograničenost smernica koje se bave materijalnošću u IFRS, posebno onih koje se odnose na obelodanjivanje u napomenama uz finansijske izveštaje. U svetlu tih saznanja, IASB je odlučio da razvije projekat o materijalnosti. Projekat će obuhvatiti subjekte koji pripremaju finansijske izveštaje, revizore tih finansijskih izveštaja i regulatorne organe, kako bi koncept materijalnosti bio podjednako dobro razumljiv svim učesnicima koji su uključeni u proces finansijskog izveštavanja. Pitanje materijalnosti treba razmatrati i sa pravnog i sa regulatornog aspekta (IFRS Foundation, April 2015).

U novembru 2014. godine IASB je odlučio da međusobno uskladi definicije o materijalnosti iz: IAS 1 Prikazivanje finansijskih izveštaja; IAS 8 Računovodstvene politike promene u računovodstvenim procenama i greške; i Konceptualne okvire za finansijsko izveštavanje. Pored toga, odlučeno je da se u stavu 1 IAS 1 jasno navedu karakteristike materijalnosti. Nacrt nove smernice IFRS Praktični savet Primena materijalnosti na finansijske izveštaje ima za cilj da pomogne rukovodstvo u primeni koncepta materijalnost pri sastavljanju finansijskih izveštaja opšte namene u skladu sa Međunarodnim standardima finansijskog izveštavanja (IFRS, 2015b).

Materijalnost je opšti koncept koji je u širokoj primeni kako u finansijskom izveštavanju tako i za druge potrebe koje mogu, ali ne moraju biti finansijske prirode. Ovaj koncept služi kao filter koji obezbeđuje da su finansijski izveštaji efektivni i razumljivi sižei informacija sadržanih u internim računovodstvenim evidencijama entiteta. Ako informacije u finansijskim izveštajima ne bi bile sažete na jasan način, ili ako bi se materijalno značajne informacije zanemarivale ili krile, finansijski izveštaji izgubili bi na razumljivosti za svoje korisnike.

Prilikom ocenjivanja da li su informacije sadržane u finansijskim izveštajima materijalne, rukovodstvo entiteta prosuđuje o tome da li se u razumnoj meri može očekivati da ta informacija utiče na odluke koje će korisnik finansijskih izveštaja doneti. Dok rasuđuje, rukovodstvo treba da razmotri kako pojedinačne okolnosti entiteta tako i način na koji će se ta informacija koristiti. Pošto se okolnosti u kojima entitet posluje neprestano menjaju, neophodno je i da se u kontekstu novih okolnosti, pri svakom sastavljaju finansijskih izveštaja, materijalnost preispituje i ponovo procenjuje. Ovo procenjivanje uključuje upoređivanje informacija iz tekuće godine sa informacijama iz prethodnog perioda, kako bi se ocenile promene u aktivnostima ili u okolnostima u kojima entitet posluje.

Za potrebe revizije finansijskih izveštaja, koncept materijalnosti razmatra se u nekoliko Međunarodnih standarda revizije, u ISA 320 Materijalnost pri planiraju i izvođenu revizije, ISA 450 Ocenjivanje pogrešno iskazanih iznosa prepoznatih tokom revizije, ISA 260 Komunikacija sa licima koja su zadužena za upravljanje organizacijom, i ISA 700 Formiranje mišljenja $i$ izveštavanje o finansijskim izveštajima. Standard ISA 320 razmatra odgovornost revizora za primenu koncepta materijalnosti pri planiranju i izvođenju revizije finansijskih izveštaja. ISA 450 objašnjava kako se koncept materijalnosti primenjuje u ocenjivanju efekata prepoznatih pogrešno iskazanih iznosa i neizvršenih ispravki tih iznosa, ako ih ima 
u finansijskim izveštajima. Koncept materijalnosti počiva na premisi da sve stavke na osnovu kojih se formira revizorsko mišljenje nisu materijalne ili značajne na isti način i u istom rangu. Takođe, od velike je važnosti odrediti prag, odnosno granicu, materijalnosti. Pozicije koje su prešle prag materijalnosti, materijalno su značajne.

\section{KONCEPT MATERIJALNOSTI U NEFINANSIJSKOM IZVEŠTAVANJU}

Nefinansijsko izveštavanje treba da obuhvati sve značajne činjenice koje mogu da utiču na sposobnost organizacije da kreira vrednost na kratak, srednji i dugi rok i koje mogu imati uticaja na dostizanje strateških ciljeva organizacije, kako pozitivnih, tako i negativnih (tj. na rizike). Ključni uticaj na obim ovog izveštavanja ima ocena materijalnosti pitanja koja su relevantna za interesne strane.

PricewaterhouseCoopers je objavio praktični vodič za primenu integrisanog izveštavanja, prema kome se strategija, misija, vizija i ciljevi organizacije ubrajaju u činioce od značaja za odlučivanje o materijalnosti. U vodiču se naglašava da je u tom procesu najvažnije da se pri utvrđivanju obima izveštavanja i uveravanja pitanje materijalnosti posmatra sa stanovišta interesnih strana. U tom smislu, sve je veći broj organizacija koje stupaju u dijalog sa svojim spoljnim interesnim stranama da bi razumele kako one doživljavaju učinak poslovanja na finansijske i druge uslove (PricewaterhouseCoopers LLP, 2015, str. 31). Primena integrisanog izveštavanja zahteva od entiteta da razvije procese za slušanje investitora i drugih interesnih grupa. To pomaže rukovodstvu da stekne uvid u pitanja koja su od značaja i da razume kako interesne strane sagledavaju mesta na kojima se kreira vrednost. Isto tako, i pružaoci usluga uveravanja treba da razumeju činioce koji utiču na odluke korisnika nefinansijskih izveštaja i na njihove potrebe.

Uveravanje u nefinansijsko izveštavanje, kako od strane eksternih, tako i od strane internih revizora je oblast u razvoju koja se suočava sa novim izazovima. Tokom razmatranja granice materijalnosti, revizori moraju posvetiti puno pažnje posedovanju odgovarajućih kompetencija iz dva razloga:

1) činjenice da je ovo revizija kvalitativnih informacija, jer predmet ispitivanja nije uvek kvantitativne prirode kao kod finansijskih informacija, $i$

2) činjenice da je ovo revizija subjektivnih informacija, jer predmet ispitivanja nije uvek objektivan - kao kod finansijskih informacija.

Pored toga, za razliku od revizije finansijskih izveštaja koji govore o prošlosti, revizija nefinansijskih izveštaja više se bavi prospektivnim informacijama (European Confederation of Institutes of Internal Auditing - ECIIA, 2015).

Zahtevi za nefinansijskim izveštavanjem su novijeg datuma, a obim ovih zahteva kreće se u širokom rasponu, što znatno otežava ocenjivanje materijalnosti informacija. Tako na primer, Direktiva 2014/95/EU o nefinansijskom izveštavanju zahteva od kompanija da u godišnjem izveštaju o poslovanju obelodane informacije o politikama, rizicima i ishodima povezanim sa činiocima iz životnog i društvenog okruženja sa aspekta zaposlenih, poštovanja ljudskih prava, pitanja borbe protiv korupcije, kao i podmićivanja i raznolikosti odbora direktora. Objavljivanje ovih informacija treba da doprinese boljem uvidu investitora u rezultate njihovog poslovanja. Direktiva ne propisuje okvir izveštavanja, već upućuje na neki od već postojećih međunarodnih okvira (UN Global Compact, OECD Guidelines for Multinational Enterprises, ISO $26000 \ldots$...) ili nekom drugom regulativom, prema izboru kompanije (Direktiva 2014/95/EU, 2014). Ovakva rešenja uslovljena su činjenicom da je ekonomski interes investitora ključni pokretač aktivnosti svake kompanije. Spremnost investitora da vodi računa o društvenim, humanim ili pitanjima životnog okruženja skoro isključivo zavisi od visine koristi, uključujući tu i naknadu štete i kazne, koju ostvaruje takvim ponašanjem.

S druge strane, pred investitore se postavljaju ozbiljni zahtevi za razmatranje interesa i ostalih učesnika čije aktivnosti ili ponašanje mogu da utiču na aktivnosti kompanija. U tom smislu dopunjuje se i definicija pojma materijalnosti. Istraživanja, koja je u 2006. godini sprovela mrežna organizacija AccountAbility, pokazuju da ozbiljna definicija „materijalnosti" mora efektivno da prepozna informaciju koja, ako se izostavi ili pogrešno prikaže, može značajno pogrešno da prikaže rezultate poslovanja i finansijski položaj organizacije njenim interesnim stranama, i na taj način utiče na njihove zaključke, odluke i akcije. Rezultati istraživanja pokazuju da definicija „materijalnosti” mora da zadovoljava i investitore, koji su uglavnom usmereni na kratak rok, kao i one koji razmišljaju na duži rok, ostavljajući mogućnost za pojavu novih, do sada nesagledanih rizika (AccountAbility, 2006).

\section{ZAKLJUČAK}

Materijalnost određuje prag značajnosti ili tačku preloma nakon koje informacija postaje merodavna za potrebe donošenja odluka od strane korisnika finansijskih i nefinansijskih informacija. Nefinansijsko izveštavanje odnosi se na objavljivanje kvantitativnih i kvalitativnih informacija koje nisu obuhvaćene finansijskim izveštajima.

Iako standardi finansijskog i nefinansijskog izveštavanja jasno navode da se njihova primena odnosi samo na materijalne stavke, skoro sve organizacije prikazuju i obelodanjuju i veliki broj nematerijalnih stavki u svojim finansijskim izveštajima. Istraživanja pokazuju da kompanije prikazuju i obelodanjuju nematerijalne informacije kako ne bi skretale pažnju regulatornih i nadzorni organa.

Klasična definicija materijalnosti polazi od pretpostavke da je interes investitora usmeren samo na rezultate finansijskog poslovanja preduzeća koje je predmet razmatranja. U tom smislu, informacija se smatra materijalnom ako može da utiče na rezultate finansijskog poslovanja na kratak ili na dugi rok. Jasno je da što je rok u kome se rezultati poslovanja razmatraju duži, broj rizika i mogućnosti koje treba razmatrati progresivno raste, pa samim tim i broj stavki koje postaju materijalno značajne.

Bitne promene u poimanju koncepta materijalnosti izazvane su sve većim zahtevima za izveštavanjem o nefinansijskim podacima i informacijama. Za razliku od retrospektivnog karaktera finansijskih izveštaja, nefinansijski izveštaji usmereni su na budućnost koja je puna neizvesnosti i rizika. Informacija koja je danas nematerijalna, već sutra može značajno da promeni svoj karakter. Kao najpogodniji način da se upravlja obimom izveštavanja danas se kao opšteprihvaćen stav smatra da pri odlučivanju o materijalnosti informacija, entiteti treba dobro da sagledaju stavove interesnih strana, $i$ to kontinuirano, kao deo svojih poslovnih politika. 


\section{LITERATURA}

AccountAbility. (2006). The Materiality Report: Aligning Strategy, Performance and Reporting. Preuzeto 18. Oktobra 2015. sa http://www.accountability.org/standards/aa1000as/index. html.

CFA Institute. (2013). Financial Reporting Disclosures: Investor Perspectives on Transparency, Trust and Volume. Preuzeto 14. Oktobra 2015. sa https://www.cfainstitute.org/learning/ products/publications/ccb/Pages/ccb.v2013.n12.1.aspx.

EUR-Lex. (2014). Direktiva 2014/95/EU Evropskog parlamenta i Vijeća od 22. listopada 2014. o izmjeni Direktive 2013/34/ EU u pogledu objavljivanja nefinanscijskih informacija i informacija o raznolikosti određenih velikih poduzeća i grupa. Preuzeto 15. Oktobra 2015. sa http://eur-lex.europa.eu/ legal-content/HR/TXT/?uri=CELEX:32014L0095

European Confederation of Institutes of Internal Auditing - ECIIA. (2015). Non-Financial Reporting: Building trust with internal audit. Preuzeto 1. Septembra 2015. sa www.eciia.eu.

Frishkoff, P. (1970). An empirical Investigation of the Concept of Materiality in Accounting. Journal of Accounting Research 8, 116-129. doi: 10.2307/2674697.

IFRS. (2015a). Staff Paper: IASB Meeting. In IASB Agenda ref 11. Preuzeto 15. Oktobra 2015. sa http://www.ifrs.org/Meetings/MeetingDocs/IASB/2015/March/AP11-Disclosure\%20 Initiative.pdf .

IFRS. (2015b). Exposure Draft ED/2015/8 IFRS Practice Statement: Application of Materiality to Financial Statements. Preuzeto 5. Oktobra 2015. sa http://www.ifrs.org/CurrentProjects/IASB-Projects/Disclosure-Initiative/Materiality/ Exposure-Draft-October-2015/Documents/ED_IFRSPracticeStatement_OCT2015_WEBSITE.pdf .
International Auditing and Assurance Standards Board - IAASB. (2014). International standard on auditing 320. In Handbook of International Quality Control, Auditing, Review, Other Assurance, and Related Services Pronouncements (pp. 321329). New York: International Federation of Accountants.

Odbor za međunarodne računovodstvene standarde - IASB. (2014a). IAS 1: Međunarodni računovodstveni standard 1 Prezentacija finansijskih izveštaja. Preuzeto 15. Oktobra 2015. sa http:// www.mfin.gov.rs/UserFiles/File/MRS/2014/IAS/IAS\%201.pdf.

Odbor za međunarodne računovodstvene standarde - IASB. (2014b). IAS 8: Međunarodni računovodstveni standard 8 - Računovodstvene politike, promene računovodstvenih politika i greške. Preuzeto 10. Oktobra 2015. sa http://www.mfin.gov.rs/UserFiles/File/MRS/2014/IAS/IAS\%208.pdf.

Odbor za međunarodne računovodstvene standarde - IASB. (2010). Okvir 2010: Konceptualni okvir za finansijsko izveštavanje. Preuzeto 10. Oktobra 2015. sa http://www.mfin. gov.rs/pages/issue.php?id=6541.

PricewaterhouseCoopers. (2015). Implementing Integrated Reporting, PwC's practical guide for a new business language. Preuzeto 20. Oktobra 2015. sa http://www.pwc.com/gx/en/ audit-services/publications/assets/pwc-ir-practical-guide. pdf.

\section{THE CONCEPT OF MATERIALITY FROM THE POINT OF FINANCIAL AND NON-FINANCIAL REPORTING}

\section{Abstract:}

Materiality is a threshold for determining the questions that are important enough to be included in the report. According to the Conceptual Framework for Financial Reporting, "materiality is an aspect of particular relevance to a specific entity that is based on the nature or/and size of the items the given information refers to."

However, financial information does not represent only the relevant phenomena, but it must credibly present the purpose of these phenomena. An increasing importance of non-financial reporting has forced the leading companies to independently seek solutions for what is considered materially significant information, taking into account the needs of stakeholders, and restrictions imposed by the natural environment and in compliance with their strategic objectives. For the needs of stakeholders, the concept of materiality should be considered both from the aspect of comprehensiveness of reporting and comprehensiveness of assurances.

\section{Key words:}

materiality,

non-financial reporting,

redefinition of materiality. 